\title{
Språkspalten
}

\section{Massens treghet}

\section{Masse er, ifølge Helmut Ormestad} i Store Norske Leksikon, tre egenskaper ved alle legemer - treg masse, tung masse og energi.

Mennesket kommer i alle størrelser og fasonger. Ett mål for å kunne definere «ideell» eller «riktig» kroppsstørrelse er «kroppsmasseindeks» (Body Mass Index). Det er vekten i kilo dividert på kvadratet av høyden i meter $-\mathrm{kg} / \mathrm{m}^{2}$.

I Tidsskriftet bruker vi helst begrepet skrevet fullt ut i løpende tekst, men vi har holdt fast ved den engelske (internasjonale) forkortelsen BMI. Andre eksempler på slike forkortelser er CK (kreatinkinase), BE (baseoverskudd), GRF (veksthormonfrigjørende faktor), PCI (perkutan koronar intervensjon), PCR (polymerasekjedereaksjon) - og (selvfølgelig) DNA.
Når det gjelder kroppsmasseindeks, er det noen forfattere som helst vil bruke «det norske» KMI, blant annet fordi den forkortelsen konsekvent vil bli benyttet i Helsedirektoratets nye retningslinjer for barn, unge og voksne, som blir publisert i 2009. KMI benyttes også i Kunnskapsforlagets oppslagstjeneste ordnett.no.

Betegnelsen BMI er brukt i Øyris Norsk medisinsk ordbok og i Gyldendals Store medisinske ordbok, og foreløpig holder vi i Tidsskriftet fast ved denne.

Men selv den tregeste masse kan beveges hvis kraften er stor nok - vi er åpne for innspill.

\section{Åslaug Flo}

aaslaug.flo@tidsskriftet.no

Tidsskriftet

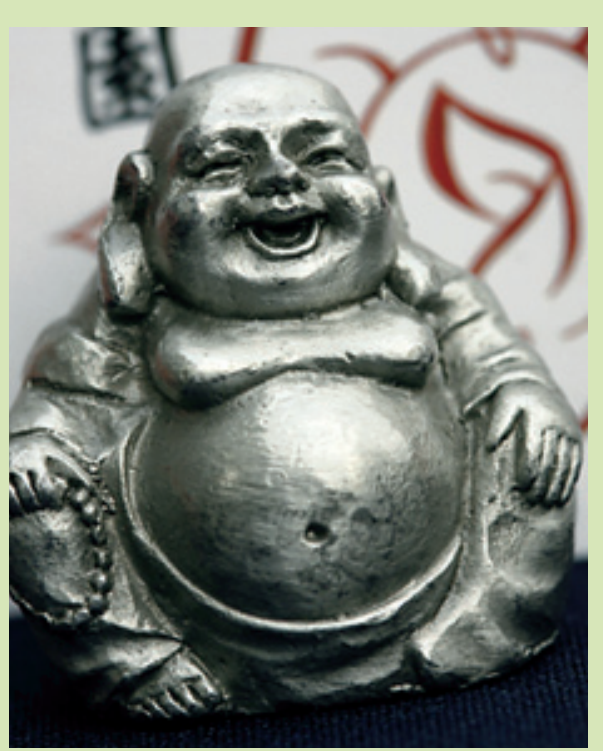

Illustrasjonsfoto Colourbox 